症例報告

\title{
吸収不良と蛋白漏出性腎炎ならびに胆管肝炎を合併した 後天性皮膚脆弱症候群の猫の 1 例 \\ Acquired Skin Fragility Syndrome with Malabsorption, Protein-losing Glomerulonephritis and Cholangiohatitis in a Cat
}

\author{
末次文雄 ${ }^{1)} *$ 川北智子 ${ }^{2)}$ 松尾咲良 ${ }^{2)}$ 代田欣二 ${ }^{2)}$ \\ 1)ママリアペットクリニック, ${ }^{2)}$ 麻布大学 \\ Fumio Suetsugu $^{1)} *$, Tomoko Kawakita ${ }^{2)}$, Sakura Matsuo $^{2)}$, Kinji Shirota $^{2)}$ \\ ${ }^{1)}$ Maria Pet Clinic, ${ }^{2)}$ Azabu University
}

Received July 25, 2017 and accepted January 25, 2018

\begin{abstract}
要＼cjkstart約：12 歳, 去勢雄の雑種猫が突然の腰部皮膚の裂傷を主訴に来院した。腰部の皮膚は不規則 に裂開し, シート状に剥離していた。皮膚組織検査で角化光進を伴う表皮の菲薄化と真皮の膠原線 維の粗鬆化が認められ，後天性皮虐脆弱症候群と診断した。本例は下顎膿瘍のための摂食障害によ り衰弱死したが, 剖検で胆管肝炎, 膜性増殖性系球体腎炎に加え, 腸絨毛の線維症が合併症として 確認された。また臨床的にも，吸収不良に配慮した消化酵素配合剂の内服で皮膚徵候の改善がみら れたため, 吸収不良が皮虐障害に密接に関連していたものと考えられた。

キーワード：吸収不良, 後天性皮膚脆弱症候群, 猫
\end{abstract}

\begin{abstract}
A 12-year-old male domestic short-hair cat was presented with a sudden laceration of the lumbar skin. The lumbar skin showed irregular tears and shedding as a large sheet. Histopathological examination of the skin revealed atrophic epidermis with hyperkeratosis, and decreased and fragmented collagen fibers in the dermis. A diagnosis of acquired skin fragility syndrome was consequently made. The present case died of asthenia with an eating disorder due to a large mandibular abscess. Necropsy and histopathological examination revealed that the cat had cholangiohepatitis, membranoproliferative glomerulonephritis, and intestinal villi fibrosis as complications of the skin lesion. Clinical improvement of the skin lesion was found after treatment with a digestive enzyme compound agent administered in consideration of the malabsorption. Therefore, malabsorption might be closely related to the skin lesion of the present case.
\end{abstract}

Key words: malabsorption, acquired skin fragility syndrome, cat

(Jpn J Vet Dermatol 2018, 24 (2): 73-76)

\section{緒 言}

猫の後天性皮膚脆弱症候群は皮膚の著しい菲薄化 と脆弱性を特徵とする稀な疾患で, 中高齢の猫に発生

*連絡先 : 末次文雄（マリアペットクリニック）

干 211-0015 川崎市中原区北谷町 101-1

TEL 044-555-3611 FAX 044-555-5433

E-mail: poteji.suetsugu@nifty.com

* Correspondence to: Fumio Suetsugu (Maria pet clinic) 101-1 Kitara-chou, Nakahara-ku, Kawasaki-shi, Kanagawa 211-0015, Japan
がみられる7,9)。原因は不明であるが，これまで合併 症としてクッシング症候群, 糖尿病, リンパ腫, 肝疾患, 猫伝染性腹膜炎 (FIP)，ネフローゼ症候群，プロジェ ステロン含有薬の過剩投与，アミロイド症，栄養失調 などさまざまな疾患の報告がある 2,3,7-13)。今回，肝疾 患，蛋白漏出性腎炎に加え吸収不良が合併症としてみ られ，消化酵素配合剂の投与により，皮膚症状が軽 快した症例を経験した。そのため, 猫の後天性皮膚 脆弱症候群の原因となる病態として吸収不良も考慮す る必要があると思われたため, 症例の概要を報告する。 


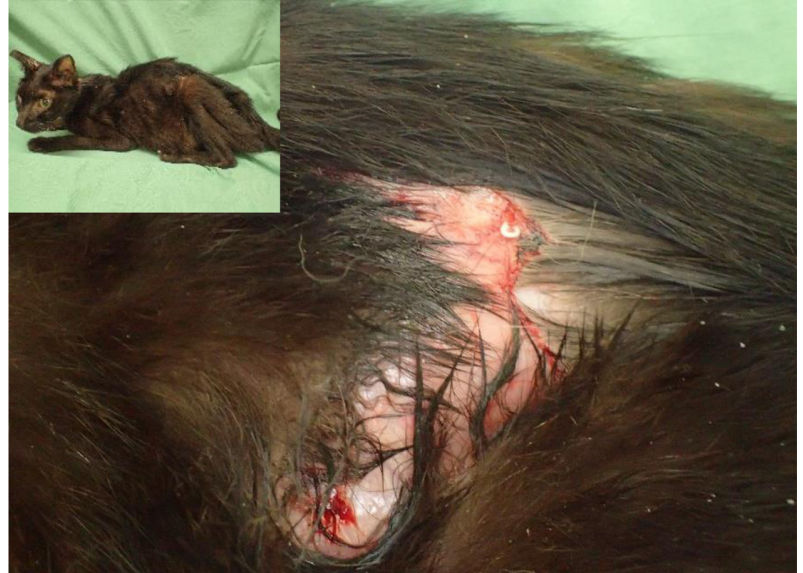

Fig. 1. Skin lesion on the lumbar area. Note the irregular tear of the skin.

\section{症例報告}

12 歳齢, 未去勢雄の雑種猫が平成 28 年 9 月 13 日, 毛繥い中に突然, 腰部の皮虐が裂けたことを主 訴に当院を受診した。1 年前から多食, 軟便, 多飲 多尿が認められ，来院時の体重は $2.25 \mathrm{~kg}$ （ボディ・ コンディション・スコア 2/5) で重度の削瘦と脱水 が認められた。な扮平成 27 年 6 月における体重は $3.6 \mathrm{~kg}$ であった。多頭飼育で特記すべき既往歴や薬 物歴はなかった。現症として, 全身の皮膚の菲薄化 がみられ, 左腰部の皮膚は広範囲に不規則に裂開し, 右腰部の皮膚は濡れたティッシュペーパーのよう にシート状に表皮剥離していた。裂開部からの出血 や疼痛は殆ど認められなかった（Fig. 1)。血液検査 では好中球数増加 $(44,600 / \mu \mathrm{l}$ 参考值 $2,500 \sim 12,500 /$ $\mu 1)$, 血中尿素窒素の上昇 $(47.1 \mathrm{mg} / \mathrm{dl}$, 参考值 17.6 $\sim 32.8 \mathrm{mg} / \mathrm{dl})$, クレアチニンの上昇 $(1.7 \mathrm{mg} / \mathrm{dl}$, 参 考值 $0.8 \sim 1.61 \mathrm{mg} / \mathrm{dl})$, 高リン血症 $(7.2 \mathrm{mg} / \mathrm{dl}$, 参考 值 $2.6 \sim 6.0 \mathrm{mg} / \mathrm{dl})$, 低カルシウム血症 $(7.7 \mathrm{mg} / \mathrm{dl}$, 参考值 $8.8 \sim 11.9 \mathrm{mg} / \mathrm{dl}$ ) が認められた。アルブミ ンは $2.6 \mathrm{~g} / \mathrm{dl}$ (参考值 $2.3 \sim 3.5 \mathrm{~g} / \mathrm{dl}$ ) であった。また, 血清ウイルス検査では猫白血病ウイルス $(\mathrm{FeLV})$, 猫免疫不全ウイルス（FIV）ともに陰性であった。 X- 線検査では消化管の著しいガス貯留による鼓腸 が認められた (Fig. 2)。腹部超音波検査では小腸壁 や副腎などに著変はみられなかった。尿検査では高 度蛋白尿（尿蛋白クレアチニン比 3.86, 参考值 0 ～ 0.4）が認められた。臨床像から, 消化器疾患なら びに蛋白漏出性腎疾患を合併した，猫の後天性皮膚 脆弱症候群と診断した。皮膚の裂開部は縫合が不可 能と判断し, 乳酸リンゲルによる洗浄を行った。第 2 病日に皮膚生検を実施したが, 皮下脂肪組織はな

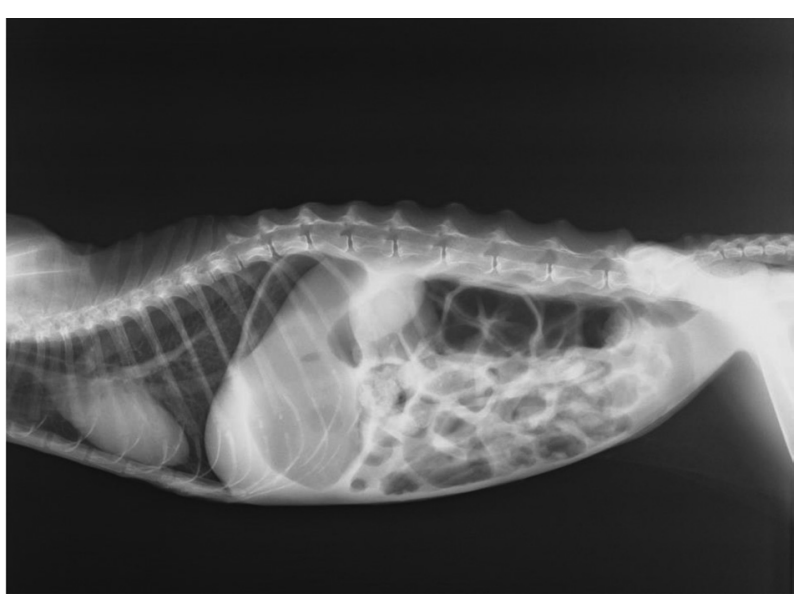

Fig. 2. Note the abdominal distension and remarkable retention of gas in the gastrointestinal tract. X-ray figure.

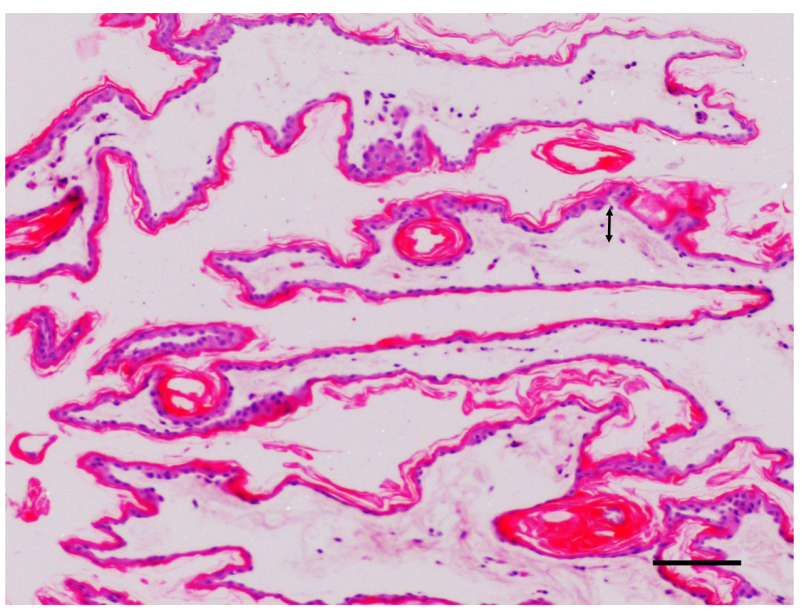

Fig. 3. Histopathology of the skin biopsy of the lumbar area. Biopsy specimen lacked subcutaneous adipose tissue, and was complicatedly curled due to severe thinning. Note highly atrophic epidermis with hyperkeratosis. Dermis was extremely thin with loosely arranged collagen fibers (two-headed arrow). (Bar=100 $\mu \mathrm{m})$.

く, 皮膚は著しく薄く柔らかく, 非常に㱀になりや すかった。皮膚病理組織検査では, 表皮の著しい菲 薄化と角化立進があり, 真皮も高度に菲薄化し、膠 原線維の粗鬆化や付属器の萎縮を伴っていた（Fig. 3)。また炎症細胞の浸潤は認められなかった（Fig. 3)。血清 $\mathrm{T}_{4}$ 值は $1.1 \mu \mathrm{g} / \mathrm{dl}$ (参考值 $0.9 \sim 3.8 \mu \mathrm{g} / \mathrm{dl}$ ), $\mathrm{ACTH}$ 刺激試験は刺激後 30 分が $6.8 \mu \mathrm{g} / \mathrm{dl}, 60$ 分が $5.4 \mu \mathrm{g} / \mathrm{dl}$ (両者ともに参考值 $6 \sim 12 \mu \mathrm{g} / \mathrm{dl}$ ) であった。 体重減少と鼓脹を伴う軟便がみられたことから，小 腸での消化吸収の促進を目的に消化酵素配合剤（工 クセラーゼカプセル, Meiji Seika ファルマ, 東京) 4 カプセル $(1,280 \mathrm{mg}) /$ 頭 / 日の内服を開始した。 


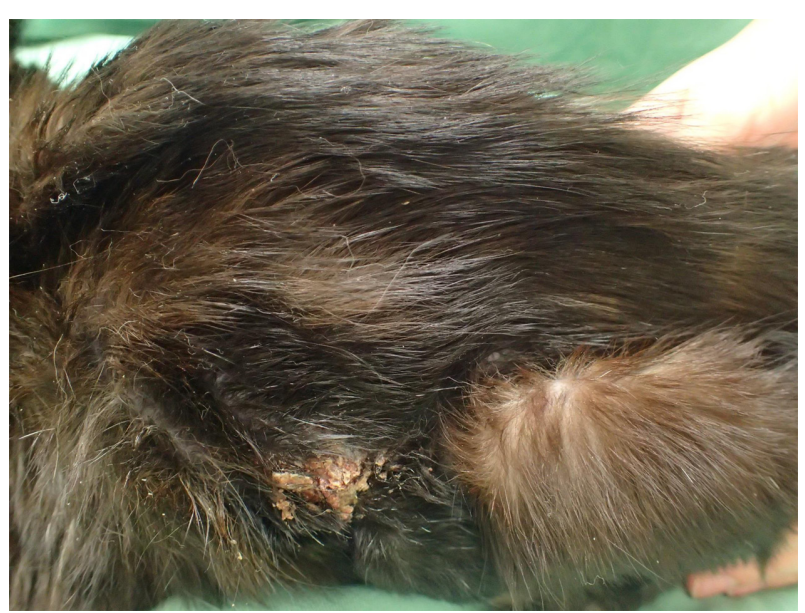

Fig. 4. A skin sample from the lumbar area. Improvement of the skin lesion after administration of digestive enzymes compounding agent (Exelase Combination Capsules).

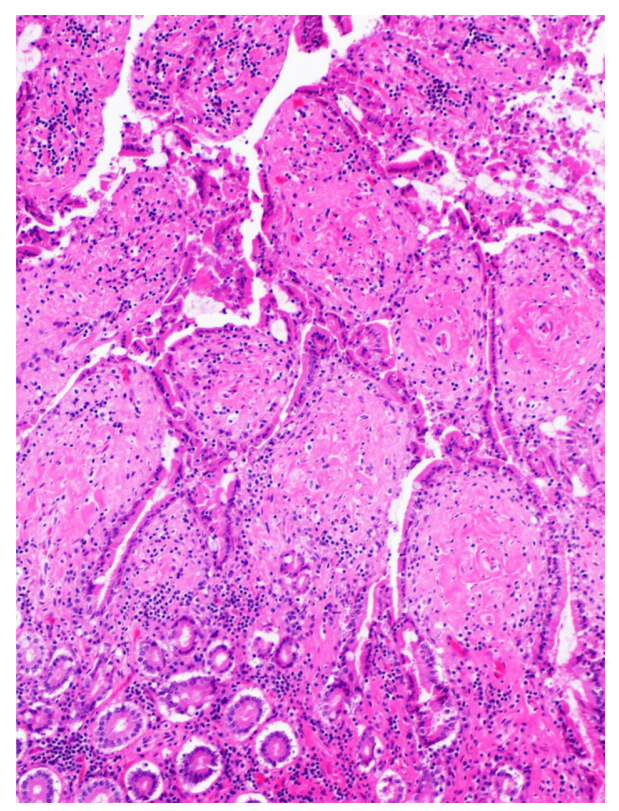

Fig. 5. Histopathology of the jejunum. Thickening of the villi due to increased collagen fibers in the lamina propria. HE. (Bar=100 $\mu \mathrm{m})$.

また,腸内環境の改善のために,アモキシシリン（パ セトシン細粒，協和発酵キリン株式会社，東京） 15 $\mathrm{mg} / \mathrm{kg}, 1$ 日 2 回の内服も行った。

第 9 病日には体重が $2.58 \mathrm{~kg}$ まで増加し, 軟便 も改善傾向にあった。猫トリプシン様免疫活性は $49.5 \mu \mathrm{g} / \mathrm{l}$ (参考值 $12.0 \sim 82.0 \mu \mathrm{g} / \mathrm{l}$ ), 猫膵特異的リ パーゼは $3.0 \mu \mathrm{g} / 1$ （参考值 $3.6 \mu \mathrm{g} / 1$ 未満）であった。

第 32 病日では体重が更に $2.84 \mathrm{~kg}$ まで増加し, 皮膚徵候や便の性状も改善したが（Fig. 4)，第 58

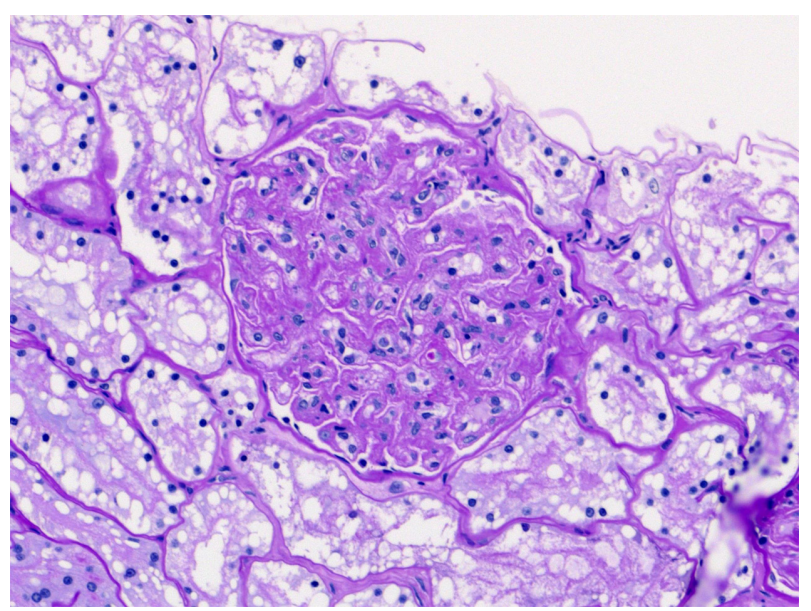

Fig. 6. Membranoproliferative glomerulonephritis showing mesangial expansion and thickening of the capillary wall with double contour configuration. PAS reaction. (Bar $=50 \mu \mathrm{m})$.

病日に急劇な左下顎の腫脹と食欲減退がみられ, その 2 日後に佂死した。整死後, 飼い主の同意が 得られたため, 病理解剖を実施した。

剖検では全身の筋肉が高度に菲薄化し, 胸筋お よび肋間筋の菲薄化のため, 剥皮後に皮下ょり肋 骨と肺が明視された。また, 左下顎部の皮下から 咬筋内, 咽頭の粘膜にかけて広範な膿瘍が存在し, 黄緑色の膿が貯留していた。組織学的に, 小腸で は全域にわたり，膠原線維の増生による腸絨毛の 肥厚がみられた（Fig. 5)。膠原線維の増生は, 粘膜 固有層に限局し, 中程度のリンパ球, 形質細胞浸 潤を伴っていた。また, 粘膜固有層の線維増生は, 大腸粘膜にも散在性に認められたが、線維化の程 度は軽度であった。腎臓では糸球体の肥大とメサ ンギウムの増殖，基底膜の二重化を特徵とする膜性 増殖性系球体腎炎が認められた（Fig. 6)。また肝臓 では濔漫性に小葉間胆管を中心とした炎症細胞浸 潤が認められ，胆管肝炎と診断された。なお，左下 顎に見られた膿瘍は咬筋を中心に形成されており， 同部では好中球が筋肉組織の壊死や細菌塊形成を 伴って高度に浸潤し膿を形成しており, 細菌検査 によって Pasteurella multocida が分離・培養された。

\section{考 察}

猫の後天性皮膚脆弱症候群では前述したような さまざまな合併症があげられているが，本例では禀 告拉よび臨床検査からクッシング症候群, 糖尿病, プロジェステロン含有薬の過剩投与, リンパ腫等 は認められなかった。一方，多食であるにも関わ 
らず重度な削瘦と著しい鼓腸を伴う軟便, 胆管肝 炎ならびに膜性増殖性糸球体腎炎が合併症として 認められた。削瘦を伴う鼓腸は膵外分泌不全や吸 収不良でみられるが 4), 臨床検査ならびに病理検査 から膵外分泌不全は否定され，吸収不良を考えた。 小動物において吸収不良は消化管に打ける栄養成 分の吸収が，分子レベルで不完全になることと定 義されている ${ }^{4)}$ 。また，腸絨毛での消化酵素の欠 そが，吸収不良の原因の一つとしていわれている。 さらに, 消化酵素の欠乏は腸緁毛に組織学的な変 化を起こす様な障害が生じた時にみられることが ある。例として, 病原性大腸菌の感染や, レクチ ンなどの刺激があげられる ${ }^{4)}$ 。また，炎症性腸疾患 において炎症反応が消化酵素に与える影響によっ て，吸収不良をもたらすことが知られている ${ }^{14)}$

本例では病理組織検査で小腸全域にわたり, 粘膜 固有層での膠原線維増生がみられ, 絨毛の肥厚が認 められた。この病理変化の機序は不明だが, 前述し たような慢性腸疾患が原因として推察され, 栄養成 分の吸収不良に関与した可能性があると思われた。

吸収不良の原因が絨毛の消化酵素の欠乏なのか, 肥厚による物理的障害なのかを明らかにすること はできなかった。消化酵素の投与は発酵性の食物 の消化を促進することで，犬や猫の鼓腸を軽減す るとされている ${ }^{6}$ 。本例でも消化酵素配合剤の内 服により, 鼓腸と軟便の改善, ならびに体重増加 が認められた。このことから, 慢性腸疾患によっ て不足した腸消化酵素を経口的に補うことで，消 化吸収が促され, 症状が改善したと推察された。

さらに胆管肝炎の発生機序として, 小腸からの 細菌の上行感染が挙げられており ${ }^{5}$, 本例の小腸 での病態が細菌の過剩増殖を引き起こした可能性 も考えられた。本症の併発疾患にネフローゼ症候 群が報告されているが 7,9), 自験例においても高度 な蛋白尿を伴う膜性増殖性糸球体腎炎が認められ, 吸収不良とともに削瘦に関与していたと思われた。

なお，今回の左下顎膿瘍は，皮膚裂傷の発生か ら58日後に認められており, それまで摂食障害な どの症状はなかった。このことから, 左下顎膿瘍 と皮膚脆弱症との関連性は低いものと思われた。

猫の後天性皮膚脆弱症候群に扮ける皮膚の病理 変化と合併症との関連は，よく分かっていない7,9)。 しかし，これまでの報告をみても，多くの症例に 重度な削瘦が認められている2,3,8, 10-13)。モルモット では, 食事制限による削瘦状態下で, 皮膚をはじめ, 様々な蔵器で, mRNA レベルでのコラーゲン合成 の低下が認められている11。皮膚の脆弱性を呈した 本例に损いても, 小腸の腸絨毛の病変による吸収
不良, 胆管肝炎, 膜性増殖性系球体腎炎の関与に よると考えられる削瘦が認められた。

著者らが調べ得た限り, 吸収不良と後天性皮膚 脆弱症候群の合併症の報告はみられない。今回の 吸収不良と皮膚病変との関連を明確にすることは できなかったが，今後，猫の後天性皮膚脆弱症候 群の合併症として吸収不良を考慮する必要がある と思われた。

\section{引用文献}

1) Anonymous. 1985. Nutr. Rev. 43: 190-192.

2) Crosaz, O., Vilaplana-Grosso, F., Alleaume, C., Cordonnier, N., Bedu-Leperlier, A.S., Marignac, G., Hubert, B. and Rosenberg, D. 2013. J. Feline. Med. Surg. 15: 953-958.

3) Daniel, A.G., Lucas, S.R., Júnior, A.R., Monteiro, P.R., Ramos, D., Pires, C.G. and Sinhorini, I.L. 2010. J. Feline. Med. Surg. 12: 151-155.

4) Ettinger, S.J., Feldman, E.C. and Côte, E. 2010. pp.175-178,1516-1564. In: Textbook of Veterinary Internal Medicine, 8th ed., Elsevier, St. Louis.

5) Ettinger, S.J., Feldman, E.C. and Côte, E. 2010. pp.1633-1638. In: Textbook of Veterinary Internal Medicine, 8th ed., Elsevier, St. Louis.

6) Ettinger, S.J. and Feldman, E.C. 2000. pp. 135136. In: Textbook of Veterinary Internal Medicine, 5th ed., W.B.Saunders, Philadelphia.

7) Gross, T.L., Ihrke, P.J., Walder, E.J. and Affolter, V.K. 2005. pp. 389-391. In: Skin Diseases of the Dog and Cat, Clinical and Histopathologic Diagnosis, 2nd ed., Blackwell Science, Oxford.

8) 石堂真司. 2011。獣医臨床皮虐科 17: 171-175.

9) Miller, W.H., Griffin, C.E. and Campbell, K.L. 2013. pp.719-723. In: Small Animal Dermatology, 7th ed., Elsvier, St. Louis.

10）宮岡友則, 福島広子, 倉繁裕美. 2005. 獣医 臨床皮膚科 11: 5-8.

11）村山信雄, 永田雅彦. 2007. 獣医臨床皮膚科 13: 91.

12) 田中史彦, 安野恭平, 浅井 厚, 筋師 健, 大塚崇史, 永田雅彦, 代田欣二. 2009. 獣医 臨床皮膚科 15: 79-81.

13) Regnier, A. and Pieraggi, M.T. 1989. J. Small. Anim. Pract. 30: 419-423.

14) Ugarte, C., Guilford, W.G. and Markwell, P. American Society for Nutritional Sciences 2004. J. Nutr. 134: 2415-2430. 